\title{
BLACK SEA REGION AND EUROPEAN SECURITY POLICY
}

\author{
Sevdalina DIMITROVA, Stoyko STOYKOV, Rumen MARINOV \\ "Vasil Levski" National Military University, Veliko Tarnovo, Bulgaria \\ sevdalinaid_bg@mail.bg; stojkods@abv.bg; marinov_r@nvu.bg
}

\begin{abstract}
It is obvious that the beginning of the 21st century is marked by many new challenges, problems and risks, which in addition to changing the ideas, concepts and practice of organized violence, lead to a deficit of ideas, methods and means of protection from it. The need to adapt available security systems, tools and practices is adopted in Europe as a response to a conscious public need rather than as a strategically planned action in a time of changes. This led to a spontaneous emergence of a common attempt to aggregate and structure the available security knowledge and to create a common stable conceptual basis for national security systems in countries not only in Europe. Moreover, the enlargement of the Union has opened up new horizons for the development of the countries and, at the same time, has changed the significance and scope of European security, where the demarcation line between external and internal security has become more and more difficult to be determined. The discussions about our country's contribution to strategic security in the Black Sea region as part of European security are in the context of the scientific search of ours science school.
\end{abstract}

Keywords: security and defense policy; European security policy; Black Sea region; Strategic Management; security management

\section{Introduction}

The dynamic development of the military strategics, the increase of responsibilities, the place and the role of the European Union (EU) on a global scale, the conclusions drawn on the problems of developing European powers call for the development of its own security strategy for the Union. The political nature of this strategy is to declare the EU's responsibilities in international politics and to identify the main threats to European security. These include terrorism, weapons of mass destruction, failed states, organized crime and regional conflicts [9]. The enlargement of the Union has opened up new horizons for the development of the countries and, at the same time, has changed the significance and scope of action of European security, whereby the demarcation line between external and internal security is becoming more and more difficult to determine. Signed in Brussels on 13.11.2017. (PESCO) is attempting to unveil a new era in European integration by laying the foundations of the European Defense Alliance [3]. With the admission of our country as a member of the Euro-Atlantic structures, which makes it the external border of the Union, the issue of our strategic contribution to the Black Sea region as part of the European security, in the context of which are our military scientific quests. 


\section{The Role of Bulgaria for the Strategic Security of the Black Sea Region}

\subsection{Security environment in the Black Sea Region}

The basis of our judgments is the existing research and analysis on the problems of the Black Sea region in the EU policies and the contribution of our country to the strategic security of this region. Without repeating the writing of the leading experts and analysts in this field and without politicizing the issues, this publication aims to highlight the role of our country as a member of the Euro-Atlantic structures for the security of the Black Sea region in the context of strategic documents and priorities the Bulgarian armed forces in line with NATO's common policy and the common European security policy [12].

Now that our country hosts the EuroPresidency, the adoption of the updated national security strategy of the Republic of Bulgaria and, in parallel, faces the challenges of the dynamic changes of the security environment (external and internal), challenges the „great powers", the actions of politicians and the public opinion. Security environment, is complicated by the permanent nature of terrorist acts, migratory flows, creating the conditions for seriously changing the customs and traditions of the Old Continent and challenges its economic stability, the dangers of the expansion and spreading of radical Islam .

The search by terrorist organizations and illegal and unrecognized regimes for new, unconventional and diverse methods and forms of combat lead to the use of terrorism, attempted use of weapons of mass destruction, unconventional combat, cyber attacks, impact the security and stability of Europe and also in a global scale.

The combination of centralized management with decentralized actions by groups in a network environment becomes a serious and difficult to predict threat requiring an adequate response and the formation of network-centric capabilities in conventional armed forces.

And if, until recently, public attention has been engaged in the positive effects of a globalizing world, it is more than ever necessary to focus on the negative ones and their implications for national and international security. Moreover, along with the acquirers, figuratively speaking, „constant” for the last years, „conflicts in Afghanistan, the Middle East and North Africa, asymmetric threats and mainly transnational terrorism, the proliferation of weapons of mass destruction, organized crime, weapons and drugs, cyber threats, demographic, energy and environmental problems, risks of technical and natural disasters, etc. [4], new risks and threats are generated. These include cyberattacks against strategically important socioeconomic institutions, the so-called ,hybrid war", not least the threat of North Korea's actions, the development and use of nuclear and missile programs outside international control.

In addition, it is not the underestimation and divergences of regional and geostrategic interests that fuel the conflicting opposition in the Black Sea region [4], which generates a direct danger to national and European security. Particular attention needs to be paid to the ability of small transnational groups using modern global infrastructure and the fall of state borders to disrupt the functioning of global financial networks, communications, transport, energy and power transmission networks. Despite the increased presence of conventional naval forces in the Black Sea region, indicative events such as the Sarafovo bombardment suggest that oil terminals (with adjacent approaches), port infrastructure and other critical infrastructure are targets that could be under threat. This more than ever requires a differentiated approach and strategy to contribute to the strategic security of the Black Sea region. [5]

Given the multi-faceted nature of the security system, our research focuses on the 
military-defense aspects of security and the contribution of the armed forces in this direction.

Our scientific quests are provoked by the need to build a strong collective defense based on a comprehensive long-term approach to ,enhancing the security and balanced reinforcement of the NATO East Flank, an adapted front presence in line with security specifics and defense of the allies from the Black Sea region, ,[4].

\subsection{What are the reasons for strengthening the NATO East Flank?}

Examining the security of the Black Sea region as part of European security, we should take into account its geostrategic and geopolitical significance for the global, regional and national security of the countries included in its scope. Regardless of the different interpretations of the region's scope, the Black Sea region, according to the definition of the European Commission $[5,6,7,8,10]$, includes, in addition to countries with an immediate outlet to the Black Sea (Bulgaria, Georgia, Romania, Russia, Turkey and Ukraine ) and those strongly influenced historically and geographically, even if they do not have direct access (Greece, Moldova, Armenia and Azerbaijan). [8] It is noteworthy that four NATO member countries, two of which are also EU members, define the external borders of the Union. At the same time, other countries included in the Black Sea region, in their historical geographic development and location, are themselves a source for generating security challenges and the defense capabilities of NATO and EU member states. The fact that Bulgaria, Romania and Turkey are part of NATO's Eastern Flank, in itself, priorities the collective defense and the armed forces of our country that need to obtain an adapted front presence in the Black Sea region.

It also defines the problems of strategic security in the region, which are to a large extent the key geographic location, natural resources also there is a variety of political, social, cultural and religious problems $[1,12]$. We are talking about the following:
- the strategic position of the region, defined as a frontier zone between Western and Eastern civilization states and which, according to the CEO of the International Center for Black Sea Studies, Sergei Chelak, „The Black Sea is a civilization crossroads that is influenced by Orthodoxy and Islam" [9], which makes it a part of European security;

- the region is a major communication and transport junction in which the movement of oil, gas and various commodities provokes the countries' desire to control the international trade as well as the formation of a unified energy system of its transit to the main users. Hence the energy factor is in the focus of the ,great powers";

- the fighting between Russia and the United States, accompanied by an arms race, demonstrations of ultra-modern systems of armaments and equipment, a circumstance which in itself increases the cost of militarization of the region;

- military political instability in Ukraine, cooperation between Russia and Turkey, Turkey's direct interest in the war in Syria, inter-ethnic conflicts and Islamization;

- the hybrid nature of the stimulated mass migration processes and the threat from the intensification of migration processes through the Black Sea region [4];

- cross-border organized crime, trafficking drugs and people, infiltration of members of terrorist and extremist organizations and cybercrime on the territory of the country. [4]

The flashback of the problematic areas of strategic security of the Black Sea region highlights the question of whether our country's defense capabilities meet the challenges of the security environment, the risks and threats to the region as well as the feasibility of the declared capabilities of the armed forces for collective defense in the region. Even in this background, in a situation of increasing resource deficit. The answer is in itself related to the actions of the armed forces of our country in the interest of collective defense, European and national security, the implementation of the 
missions of the Air Force in support of the implementation of the Program for development of the defense capabilities of the Bulgarian Armed Forces 2020, The Military Forces Development Plan by 2020, the European security and defense policy.

2.3. What action is being taken in the interest of the security of the Black Sea region as a factor of European security?

Despite the insufficient resource provision of the implementation of our country's armed forces programs in recent years and the implementation of the Capability goals, changes in the security environment near the Black Sea region to address new challenges and threats introduce new approaches to use of the on-duty forces and means to secure the sovereignty of our country. Thus, jointly with the allied forces and means, after the necessary changes in the national legislation and the creation of new regulations and administrative documents, the joint mission for the security of the airspace with forces and means of the USA was realized. The agreements on cross-border airspace operations with Romania and Greece are being implemented. Significant crossborder airspace operations have been carried out within the framework of NATO's Integrated Anti-Air Defense and Anti-Missile Defense System as well as bilateral agreement on cross-border operations with Turkey. The participation of the Air Force of our country in national and international exercises, training and preparation together with forces from Allied countries on the territory of our country, incl. The „Thracian Eagle”, NATO's Noble Jump-2017, Active Fence in Turkey, cross-border operations with the Greek Air Force in the „GREEN BRIDGE', operation, is indicative of collective defense and the guarantee of the security of NATO's eastern flank. This is also the involvement of the Navy and the Special Operations Forces of our country in joint exercises with the NATO member states on the preparation and maintenance of the declared forces for participation in
NATO and EU missions and operations and on the protection of the state border, including „Breeze 2017”, „Sea Guardian”, „Blace Sea Rotational Forse" and others. We should add to them the various operations and joint exercises of our country's troops and allied forces, the certification of different formations under NATO standards, as well as the logistic support of the Directorate-General Border Police - the Ministry of Interior at the Bulgarian-Turkish border for countering migratory pressure $[3,11,12]$

Last but not least, the inclusion of our country in the "Intelligent Defense" and „Uniting and Sharing” initiatives to build joint defense capabilities through complementarity and avoidance of duplication with NATO projects should also be considered.

Last but not least, as an active member of the EU, the aspirations of our country are to develop future-oriented capabilities defense and civilian in support of which it is ready to participate in the development of disarmament, demobilization and reintegration , through organizing, certifying and conducting courses, training of specialists outside the country, field exercises to prepare for participation in stabilization and reconstruction operations $[10,11,12,13]$

All this confirms the joint action on the preparation of our armed forces for participation in collective defense and the formation of the necessary defense capabilities to enhance the security and balanced reinforcement of NATO's Eastern flank in the Black Sea region, according to the comprehensive approach. This means that the system of analysis should understand the security environment as a system by harmonizing all military and non-military means throughout the engagement space to take appropriate action to respond to changes in the security environment. Hence, the relevance of key performance indicators to assess the level of performance of the planned activities and to measure the effectiveness of achieving the 
Capability Objectives. And this in itself means managing results by observing the dependency ,resources-capabilities-effects” In line with the long-term vision of the necessary European capabilities. The goal of the European Union forces is aimed at reaching the necessary capabilities for conducting modern high-tech operations, part of which are on the NATO East Front in the Black Sea region. $[5,6]$

\section{Conclusions}

In conclusion, as a country that has successfully survived 13 centuries in one of the most windy places in world history, we are interested and appreciate as particularly important the development and strengthening of our European as well as our transatlantic relations, helping to strengthen multilateralism in international relations as a guiding principle in the EU's security strategy. As part of European security and that of NATO is the security of the Eastern Flank, and especially in the Black Sea region, our country's contribution to collective defense is in its adapted front presence in this region and parallel to that in the Balkans, based on the comprehensive approach in engaging with NATO member countries.

\section{References}

[1] Baev, Y., the Black Sea Region in the international security environment and the new risks and challenges for Bulgaria, statement of the Black Sea round table - a Security Wall or a Political Door? „From the series of debates” Bulgarian Foreign Policy after the Accession to EU - from East to West or from West to East ?, organized by the IMI and the Friedrich Ebert Foundation, Sofia, 12 April 2016 http://eiri.bg/2657-2/

[2] Belova, G., N. Marin, Multi-Sectoral security dimensions in the Black Sea region, National Round Table „National Security and Migration Pressure”, April 11, 2016, SWU „Neofit Rilski” Blagoevgrad. 6\% 20 Multiple\% 20 Dimensions 20\%\% 20 Security\% $20 \mathrm{c} \%$ 20Cermontan \% 20region, \% 20 (2) .pdf, p.

[3] Twenty-three EU Member States signed in Brussels a document laying the foundations for a European Defense Alliance - the Permanent Structured Defense Cooperation Agreement (PESCO) - 13.11.2017 - https:/europa.eu/european-union/topics/foreignsecurity-policy_bg

[4] Report on the status of the Armed Forces of the Republic of Bulgaria 2016, Sofia, July, 2017, www.md.government.bg/ bg /doc / drugi /20170905 Doklad_za_sustoyanieto_na_otbranata_VS_2016.pdf, p.6.8 .

[5] Dyulgerova, N., The Black Sea Security Zones, http://ninadulgerova.org/Statii/ZonesofSecurity.pdf

[6] European Security Strategy - A Secure Europe in a Better World. https://www.mod.bg/bg/doc/strategicheski/20110401_ESS.pdf

[7] European Commission. Communication from the Commission to the Council and the European Parliament. Black Sea synergy: A new regional cooperation initiative. COM (2007) 160 final. Brussels: EC.

[8] Kirova, S., Importance and Challenges of the Black Sea Region for Bulgaria, Scientific Works of the University of Rousse-2015, Volume 54, Series 5.2, p.81.

[9] Marin, N., „Specifics, trends and perspectives of the common european security and defense policy", International Politics, Journal of the Law and History Faculty of Southwestern University Blagoevgrad, University Press St. Ohridski pp. 31-32

[10] Marinov, P. Terrorism - Abstractions and Realities. East-West, 2016 -ISBN 619152866-3

[11] Marinov P, Contemporary Challenges to Security System Management and Countering Terrorism, East-West, 2017. -ISBN 978-619-01-0027-0 
[12] The priorities for the development of the Bulgarian Armed Forces are in line with NATO's common policy and vision, https:/www.md.government.bg/bg/news.php.

[13] Security Issues in the Black Sea Region in XXIth, No. 4, 2012, https:/geopolitica.eu/spisanie-geopolitika/119-2012/broi4-2012 / 1765 -problemi-nasigurnostta-v-chernomorskiq-region-prez-xxi-vek. 